\title{
Dziecko w sieci zagrożeń - ryzykowne zachowania internetowe dzieci i młodzieży jako wyzwanie dla edukacji
}

DOI: $10.47050 / 65591777.40-67$

Maciej Tanaś, Sylwia Galanciak

Celem artykułu jest zaprezentowanie złożoności kwestii zagrożeń związanych z obecnością dzieci i młodzieży w cyberprzestrzeni. Autorzy podejmują próbę usystematyzowania tej problematyki i przedstawienia najbardziej niebezpiecznych zjawisk. Opisują także i klasyfikują najnowsze zagrożenia, podkreślając, że na skutek dynamicznego rozwoju internetu ich katalog nieustannie się powiększa, tym samym wymaga ciągłych uzupełnień. Ważną funkcję w procesie monitorowania zagrożeń, przeciwdziałania im i łagodzenia ich skutków odgrywa edukacja medialna, której znaczenie w systemach edukacji na całym świecie jest coraz większe, w Polsce jednak pozostaje kwestią bagatelizowaną.

\section{Słowa kluczowe:}

zagrożenia cyberprzestrzeni

\section{dziecko w internecie}

cyberprzemoc

hacking

sexting

patostreaming

edukacja medialna 


\section{A child in the network of threats - risky online behavior of youth as a challenge for education}

DOI: $10.47050 / 65591777.40-67$

Maciej Tanaś, Sylwia Galanciak

The aim of the article is to present the complexity of the issues of threats related to the presence of children and young people in cyberspace. The authors attempt to systematize the problem, as well as identify the most dangerous phenomena. They also describe and classify the latest threats, stressing that as a result of the dynamic development of the internet, their catalogue is constantly growing, and thus requires regular updates. An important role in the process of monitoring threats, counteracting them and mitigating the effects should be played by media education, whose importance, although growing in education systems around the world, remains a trivial matter in Polish education.

\section{Keywords:}

\section{cyber dangers}

child in the internet

cyberbullying

hacking

sexting

patostreaming

media education 
Szybkie tempo sieci i potężna presja grupy rówieśniczej, by nie wysiadać, zwiększaja prędkość bieżni, po której biegną nasze dzieci - aż do momentu, w którym już dalej nie mogą. Michael Schulte-Markwort

\section{Wprowadzenie}

Trudno uwierzyć, że internet - medium, którego powstanie wywołało największą od czasu wynalezienia druku zmianę kulturową o charakterze totalnym, obejmującą zjawiska społeczne, ekonomiczne, polityczne i osobowe - dopiero stosunkowo niedawno okrzepł w fazie wczesnej dorosłości, a jego właściwa, rewolucyjna odsłona w formule 2.0 do tej dopiero się zbliża do tego momentu. W ciągu dwudziestu ośmiu lat, które minęły od stworzenia przez Tima Bernersa-Lee języka HTML i pierwszej strony internetowej udostępnianej przez serwer WWW, liczba internautów przekroczyła cztery miliardy. Media społecznościowe, dostępne zaledwie od trzynastu, czternastu lat, gromadzą dziś ponad trzy miliardy aktywnych użytkowników. Liczba tych użytkowników przyrasta rok do roku o około 14\% (Kemp 2018). Same nowe technologie także nie wytracają rozwojowego impetu. Zgodnie z prawem sformułowanym w 1965 r. przez Gordona Moore'a moc obliczeniowa komputerów wciąż co około dwa lata się podwaja (por. Sienkiewicz 2015, s. 100). Nieuchronnie zbliża się ku kresowi fizycznych możliwości - pojawia się bowiem pytanie: „Jak zbudować tranzystor mniejszy od atomu?".

Oznacza to postępujący w tempie wykładniczym rozwój środków komunikowania i rozrywki, narzędzi poznania i pracy skupionych w sieci - wciąż jeszcze nowej, a tak zmiennej przestrzeni ludzkiej aktywności. Ta migotliwość internetu, jej proteuszowy charakter, czynią z niego szczególnie trudny obszar badań społecznych, koniecznych przecież do przeprowadzenia w sytuacji jego bezprecedensowego globalnego znaczenia. Cyfrowy świat oferuje bowiem użytkownikom niezwykłe możliwości samorozwoju, dzielenia się wiedzą, nawiązywania cennych kontaktów czy wreszcie różnorodnej rozrywki, jednocześnie jednak stanowi terytorium pełne pułapek i zagrożeń o coraz bardziej złożonym charakterze. 


\section{Zagrożenia cyberświata. Próba mapowania nowego terytorium}

Zagrożenia cyberświata mogą mieć dwojaki charakter, związany bezpośrednio z historią i ze specyfiką cyfrowego medium. W momencie jego powstania w odsłonie Web 1.0, zaprojektowanej do przekazywania treści tworzonych przez niewielu nadawców dla wielu odbiorców (tzw. struktura gwiazdy), pojawił się problem szkodliwych materiałów zamieszczanych na stronach WWW. Od początku widoczny był także problem związany z naruszeniami poufności dostępu do danych. Drugi typ zagrożeń, który narodził się w sieci wraz z jej przemianą w wersję 2.0, związany jest z zachowaniem człowieka w internecie i typami aktywności podejmowanymi przez użytkowników. Web 2.0 oznacza zupełną zmianę filozofii myślenia o kształcie sieci i roli internauty. Odejście od podziału na osoby publikujące i czytelników ku modelowi, w którym każdy może tworzyć treści, spowodowało głębokie przemiany zarówno w samej strukturze internetu, jak i w postawach jego użytkowników - teraz aktywnych twórców materiałów cyfrowych, komentatorów i sędziów wirtualnego życia, coraz silniej splatającego się z życiem realnym. Wśród tych użytkowników pojawiają się zaś osoby z różnymi kompetencjami komunikacyjnymi, kulturowymi i społecznymi, posiadający zróżnicowane umiejętności, cele i potrzeby, wreszcie - osoby w różnym wieku. Ogromny odsetek stanowią dzieci-grupa szczególnie narażona na cyfrowe zagrożenia.

Jako "cyfrowi tubylcy" - żeby przywołać słynny termin Marca Prensky'ego (2001a; 2001b) - z odwagą i łatwością poruszają się intuicyjnie w przestrzeni internetu. Obszerne badania przeprowadzone przez Naukową i Akademicką Sieć Komputerową (NASK) w 2016 r. (Kamieniecki i in. 2017, s. 13-16) pokazują, że średni wiek inicjacji internetowej wynosił u badanych nastolatków dziewięć lat i cztery miesiące, a dziś prawdopodobnie jest jeszcze niższy, rośnie bowiem pokolenie tabletowych i smartfonowych dzieci, które od maleńkości obcują z ekranami dotykowymi. Co znamienne, badani gimnazjaliści i licealiści najczęściej deklarują także, że nikt ich nie uczył korzystania z sieci, a kompetencje cyfrowe zdobyli samodzielnie ( $68,6 \%$ wskazań). Sytuacja nie tylko czyni z nich potencjalne łatwe ofiary internetowej przestępczości i zagrożeń społecznych, ale także umożliwia im wejście w rolę sprawcy, nierzadko nieświadomego dramatycznych realnych konsekwencji swoich wirtualnych działań. 
Lista niebezpieczeństw, na które narażony jest młody internauta, jest obszerna i trudna do zamknięcia ze względu na niezwykłą dynamikę ewolucji sieci. Osoby zajmujące się tą problematyką podejmują próby jej systematyzacji, kończące się zwykle konstatacją, że wszelkie listy muszą być regularnie aktualizowane ze względu na pojawiające się nowe rodzaje zagrożeń.

Użyteczną klasyfikację proponują Anna Andrzejewska i Józef Bednarek, co znamienne, poprzedzając wyliczenie wyrażeniem „między innymi":

$\rightarrow$ infoholizm (siecioholizm, netoholizm),

$\rightarrow$ dolegliwości zdrowia psychicznego i fizycznego, w tym: choroby wzroku i słuchu, schorzenia układu kostno-szkieletowego, tendencje autodestrukcyjne,

$\rightarrow$ zagrożenia poznawczo-intelektualne, obejmujące między innymi trudności z aktywnym przyswajaniem wiedzy, brak umiejętności weryfikacji informacji, zamknięcie w bańce informacyjnej,

$\rightarrow$ zagrożenia moralne, takie jak: cyberpornografia, prostytucja w sieci, sexting, sponsoring i inne,

$\rightarrow$ niebezpieczeństwa społeczno-wychowawcze dotyczące zwłaszcza postaw, zachowań, relacji i więzi, takie jak: cyberprzemoc i agresja w sieci, hazard internetowy, zaburzenie kontaktów interpersonalnych czy wykorzystywanie internetu przez sekty jako nowej, słabo nadzorowanej przestrzeni werbunkowej,

$\rightarrow$ negatywne skutki zażywania substancji chemicznych, o których źródłem wiedzy i inspiracji jest przestrzeń internetowa (narkotyki, dopalacze, leki o działaniu psychoaktywnym, sterydy i inne formy dopingu sportowego),

$\rightarrow$ ryzykowne zachowania z zakresu przestępczości teleinformatycznej, w tym: łamanie praw autorskich, hacking, bezprawne niszczenie informacji, sabotaż komputerowy, rozpowszechnianie wirusów komputerowych czy przestępstwa przeciwko wiarygodności dokumentów (Andrzejewska, Bednarek 2018, s. 28-29).

Nieco bardziej szczegółowy podział cyberzagrożeń przeprowadza Sylwester Bębas, który wyróżnia siedem podstawowych kategorii:

1. Kontakty z nieodpowiednimi treściami:

$\rightarrow$ cyberpornografia,

$\rightarrow$ cyberprostytucja (w tym także sexting prowadzący do osiągania korzyści materialnych), 
$\rightarrow$ treści propagujące niezdrowy tryb życia.

2. Niebezpieczne działania: cyberprzemoc, sexting, samobójstwa z inspiracji i pod wpływem sieci (w tym samobójstwa transmitowane na żywo w internecie, samobójstwa pod wpływem upokorzenia czy gnębienia doznanego w sieci, instruktaże dla samobójców, a także internetowe pakty samobójcze).

3. Niebezpieczne kontakty:

$\rightarrow$ uwodzenie dzieci online (child grooming),

$\rightarrow$ cyberpedofilia.

4. Naruszanie prywatności (cyberstalking).

5. Zagrożenia o charakterze seksualnym (sexting, cyberseks).

6. Zespół uzależnienia od internetu (internet addiction disorder, IAD), w tym od informacji, pozostawania online (fear of missing out, FOMO) oraz od relacji społecznych budowanych i podtrzymywanych w sieci.

7. Cyberprzestępczość i nieuczciwość w sieci:

$\rightarrow$ zagrożenia związane $z$ bezpieczeństwem danych przechowywanych w internecie,

$\rightarrow$ fałszywe lajki i pliki cookies zawierające szkodliwe oprogramowanie,

$\rightarrow$ fałszywe witryny i wyłudzenia danych,

$\rightarrow$ ataki hakerskie na serwisy społecznościowe,

$\rightarrow$ tabnabbing (fałszywe witryny internetowe podszywające się pod inne serwisy),

$\rightarrow$ clickjacking (maskowanie odnośnika w celu skłonienia użytkownika do kliknięcia w link podsunięty przez przestępcę),

$\rightarrow$ zagrożenia dla systemów mobilnych (Bębas 2018, s. 36-44).

Wiele zagrożeń powoduje „[...] rozmycie autentyczności tożsamości i jej wirtualne zwielokrotnienie w cyberprzestrzeni. W życiu codziennym czy w mass mediach nadawca charakteryzuje się określoną tożsamością. Wiele się o nim wie lub można się dowiedzieć, gdyż identyfikuje się go z określoną orientacją światopoglądową i prezentowaną rolą społeczno-zawodową. Tożsamość ta określana jest przez język ciała, gesty, barwy i tempo wypowiedzi, sposób zachowania w kontaktach bezpośrednich, pośrednich, audiowizualnych i, w mniejszym stopniu, audytywnych. Internet natomiast, znosząc ograniczenia czasoprzestrzenne, stwarza olbrzymie szanse do ukrywania autentycznej tożsamości, manipulowania nią i samokreowania przeróżnych jej postaci" (Gajda 2006, s. 16). 
Wydaje się, że internet stwarza dwie możliwości: z jednej strony pozwala na kształtowanie przez internautę tożsamości wyobrażanej lub pożądanej (na przykład w mediach społecznościowych, na witrynie instytucji, w prowadzonej korespondencji czy na własnej stronie), z drugiej - obecność w sieci i tworzone w niej informacje pozwalają dokonać analizy dostarczającej znacznie pełniejszej i precyzyjniejszej wiedzy o ich twórcy, a zarazem odbiorcy informacji i komentarzy pozostawianych przez inne osoby. Bez wątpienia jednak to - jakże częste i powszechne - zastępowanie kontaktu bezpośredniego przez kontakt medialnie zapośredniczony ma swoje społeczne, osobowe i edukacyjne konsekwencje.

Współczesne generacje, w przeciwieństwie do poprzednich pokoleń, wyrastają w otoczeniu wielu mediów. Takie środowisko pozostawia głębokie i trwałe ślady w umyśle dziecka, ponieważ media są nie tylko przekaźnikami informacji, ale także wzbudzają emocje, kształtując sferę wyobraźni, budzą pragnienia i marzenia, mieszając hierarchie wartości i osiągając cele tylko częściowo zbieżne z oczekiwaniami rodziców, pedagogów i nauczycieli. Pojawiają się problemy związane z manipulacją, propagandą, lobbingiem, kłamstwem, a także nowe definicje rzeczywistości, procesu i rezultatu poznania, prawdy i mądrości (Postman 2005, s. 20-21). Wymagają one postawienia diagnozy, lecz również podjęcia działań profilaktycznych i terapeutycznych. Powstająca dzięki elektronicznym mediom nowa powłoka kultury zmienia i rozszerza nasze zmysły oraz postrzeganą rzeczywistość. Wywiera wpływ na ludzki umysł, psychikę i stosunek do świata (Kerckhove 1997).

Portale społecznościowe sprawiły, że materiały może opublikować każdy, kto ma dostęp do sieci. Są one śladami ludzkiej myśli i twórczości, ale także dowodem naiwności, agresji i zachowań przestępczych. Działalność człowieka - jego zarówno wielkość i dobro, jak i podłość czy zło - dzięki powszechnej łączności internetowej zyskały potężne narzędzia wsparcia. Ludowe powiedzenie głosi, że „słowo gołębiem wyleci, a kamieniem wraca". Sieć sprawia, że zwiększyła się liczba kamieni, wzrosły jednocześnie ich zasięg i siła rażenia.

Sieci informatyczne łączą instytucje i ludzi, równocześnie jednak coraz bardziej uwidaczniają się dysproporcje między krajami, które inwestują w infrastrukturę teleinformatyczną, a tymi, których na to nie stać. Władza nad systemami informacji wiąże się ze zmonopolizowaniem kultury i oddziaływań politycznych. Postępują procesy homoge- 
nizacji kultury, choć równolegle żywa jest aktywność zmierzająca do zapisu brzmienia i cech specyficznych języków oraz kształtu kultur etnicznych. Trudno obecnie przesądzić, czy w XXI w. będzie dominować fatalistyczny paradygmat unicestwiania światowej różnorodności kulturowej i lingwistycznej, jej hybrydyzacja, wymieranie języków, grup lingwistycznych oraz wielu kultur lokalnych, czy też cyfrowe narzędzia technologii informacyjno-komunikacyjnych okażą swoją użyteczność w zachowaniu autentycznego pluralizmu oraz oryginalności języków i kultur (Mayor 2001, s. 355-373) oraz czy będą sprzyjać realizacji paradygmatu przetrwania i rozwoju, słowem - ratowaniu skarbów dziedzictwa kulturowego.

Sieć może być także narzędziem wojny. Warto zauważyć, że swobodny przepływ obrazów i słów w wymiarze globalnym ułatwia działalność przestępczą. Grupy przestępcze są ponadnarodowe - bezwzględnie wykorzystują one do swoich celów różnice prawa w poszczególnych krajach.

Brak powszechnej edukacji medialnej skutkuje niepożądanymi skutkami - dotyczy to wszystkich sfer użytkownika: osobowej, społecznej, kulturowej, politycznej i ekonomicznej. Od lat środowiska akademickie i oświatowe bezskutecznie apelują o jej realizację w programach kształcenia pedagogów i nauczycieli oraz w szkołach. Podobnie jak w dziedzinie prawodawstwa konieczne jest opracowanie stosownych ram legislacyjnych, które umożliwią bezpieczne poruszanie się po sieci autostrad i dróg internetu, tak wyzwaniem dla polskiej oświaty i polityki u progu XXI w. jest powszechna edukacja informacyjna i medialna. Dziś jest ona niezbędna bardziej niż kiedykolwiek.

Obowiązujące w Polsce regulacje dotyczące sfery medialnej to ujednolicony system klasyfikacji programów telewizyjnych, a także europejski system oceniania gier komputerowych PEGI (Pan European Game Information), znany także pod nazwą Ogólnoeuropejskiego Systemu Klasyfikacji Gier (OSKG). Bez wątpienia jest to jeden z najlepszych systemów klasyfikacji i oceny gier komputerowych, ale nie jedyny. Obok niego istnieją także inne rozwiązania: japońskie CERO, amerykańsko-kanadyjskie ESRB (Entertainment Software Rating Board), brytyjska ELSPA (Entertainment and Leisure Software Publishers Association), USK (Unterhaltungssoftware Selbstkontrolle) - stworzony przez niemiecką organizację oceniającą gry komputerowe i szeroko pojęte oprogramowanie rozrywkowe pod kątem bezpieczeństwa dzieci i młodzieży, 
a także OFLC (Office of Film and Literature Classification) australijskiej Komisji Klasyfikacyjnej.

Czy zatem istniejące rozwiązania w zakresie ochrony dzieci przed negatywnymi konsekwencjami gier komputerowych i dostępu do sieci można traktować jako wystarczające i ostateczne? Trzeba tutaj uwzględnić, że żadna dekretacja nie przyczynia się do wzrostu wiedzy i świadomości. Etykietka na produkcie jest tylko znakiem, którego odczytanie zależy od posiadanej wiedzy - samo oznaczenie nie jest zaś produktem. Dostępne są prace wskazujące niebezpieczne dla człowieka skutki przebywania w cyberprzestrzeni i korzystania z mediów. Warto przywołać choćby książki Manfreda Spitzera Cyfrowa demencja i Giovanniego Sartoriego Homo videns. Człowieka określa się różnie (Homo sapiens sapiens, Homo volens, Homo creator, Homo faber, Homo sedes), ale "człowiek otępiały" nie wydaje się najlepszym etapem w rozwoju istoty ludzkiej.

Poziom notowanych zagrożeń i sygnalizowane potrzeby społeczne wymagają koordynacji działań na rzecz bezpieczeństwa dzieci w cyberprzestrzeni. Niezbędne jest podjęcie całościowych działań społecznych w zakresie powszechnej edukacji medialnej i profilaktycznych programów wychowawczych. Konieczne są również działania legislacyjne $w$ tym zakresie. Coraz bardziej uwidacznia się potrzeba stworzenia narodowej strategii w tym zakresie, zwłaszcza w wymiarze odważnego i olbrzymiego programu Ogólnopolskiej Sieci Edukacyjnej’, mającego doprowadzić szerokopasmową sieć do wszystkich szkół w Polsce.

Inicjatywa Ogólnopolskiej Sieci Edukacyjnej ma celu zapewnienie powszechnego i równego dostępu szkół do bardzo szybkiego (co najmniej $100 \mathrm{Mb} / \mathrm{s}$ ), bezpiecznego i bezpłatnego internetu. Zgodnie z założeniami projektu wszystkie szkoły podstawowe i ponadpodstawowe mają do 2021 r. zostać podłączone do Ogólnopolskiej Sieci Edukacyjnej. Por. M. Bochenek, Rok pilotażu OSE [w:] Akademia NASK, O OSE - akademia.nask.pl/projekt-48/o-projekcie. html [dostęp: 17.07.2018]. Ustawa o Ogólnopolskiej Sieci Edukacyjnej została podpisana przez Prezydenta Rzeczypospolitej Polskiej i ogłoszona 28 listopada 2017 r. w Dzienniku Ustaw (Dz.U. 2017, poz. 2184, t. 1). 
Ilustracja 1. Zagrożenia osobowe, społeczne i kulturowe wynikające z rozwoju cyberprzestrzeni w ujęciu Macieja Tanasia
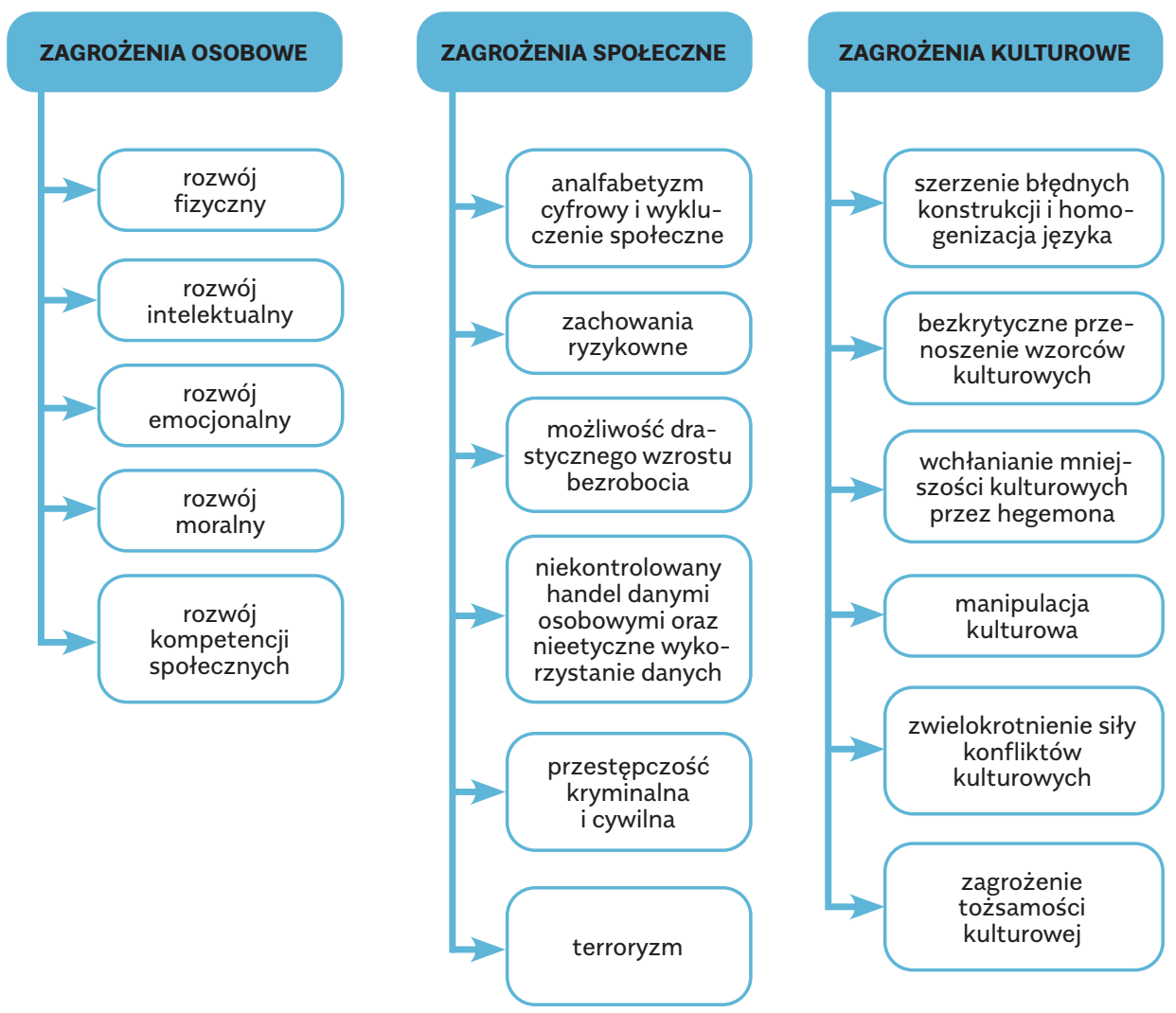

Źródło: Opracowanie własne.

2 Wcześniejsza, niepełna wersja tego ujęcia zagrożeń - por. M. Tanaś, Primum non nocere a internetowa przestrzeń wolności i aktywności nastolatków, [w:] Nastolatki wobec internetu, red. M. Tanaś, Naukowa i Akademicka Sieć Komputerowa, Warszawa 2016, s. 41-55. Przedstawiłem ją także w niepublikowanym wystąpieniu Primum non nocere @ cyberprzemoc. 25 lat Konwencji o Prawach Dziecka. Prawo dziecka do życia bez przemocy podczas konferencji naukowej „Prawo dziecka do życia bez przemocy”, zorganizowanej w listopadzie 2014 r. przez Prezydenta Rzeczypospolitej Polskiej i Rzecznika Praw Dziecka. 
Każdy, kto buduje system, chciałby, żeby był zwarty, zamknięty i spójny. llustracja 1 nie przedstawia pełnego systemu, co najwyżej systematoid, ponieważ wiele zjawisk związanych z rozwojem technologii informacyjno-komunikacyjnych nie doczekało się jeszcze badań, opisu i wyjaśnienia.

Spróbujmy wskazać niektóre zagrożenia osobowe. Część z nich wiąże się z rozwojem fizycznym dzieci i młodzieży, a dotyczy układów kostnego, nerwowego, krążenia i przemiany materii. Groźne wydają się zwłaszcza:

$\rightarrow$ niedorozwój układu mięśniowo-szkieletowego,

$\rightarrow$ wady postawy, w tym: skolioza i zniesienie lordozy w odcinku szyjnym kręgosłupa, zespół cieśni nadgarstka, choroby ramienia, karku, zmiany zwyrodnieniowe,

$\rightarrow$ obniżenie wydolności fizycznej i ogólne osłabienie organizmu,

$\rightarrow$ otyłość, choroby jelit,

$\rightarrow$ wady wzroku oraz choroby spojówek i zapalenie rogówki,

$\rightarrow$ alergie,

$\rightarrow$ konsekwencje szkodliwego oddziaływania pola elektrostatycznego i pola elektromagnetycznego (zwłaszcza częstotliwości od $10 \mathrm{kHz}$ do $300 \mathrm{kHz})^{3}$.

Przed wieloma $z$ wymienionych zagrożeń ostrzegano już w epoce rozwoju mikrokomputerów i monitorów kineskopowych (Tanaś 1993, s. 127-132). Nie dostrzegano jednak wówczas kwestii bezpieczeństwa dzieci i młodzieży (lub bagatelizowano te zagadnienia) w przestrzeni tworzonej przez łączące $w$ sobie cechy wielu mediów, coraz bardziej polisensoryczne, interaktywne i jakże atrakcyjne dla użytkowników komputery włączane $w$ sieć. Nie rozumiano również tego, że internet stanie się wkrótce miejscem realizacji twórczości, ale także polem wojen gospodarczych, ideologicznych i politycznych. Obszarem realizacji marzeń, jednocześnie zaś handlu ludzkimi organami. Rynkiem globalnych działań ekonomicznych i miejscem występowania podłości. O ile przestrzeń fizyczna była od wieków legislacyjnie kodyfikowana, 
o tyle cyberprzestrzeń pod fałszywym pretekstem nieograniczonej wolności stawała się miejscem działań przestępców oraz kontrolowania człowieka i zbiorowości społecznych.

Kolejna zatem grupa niebezpieczeństw wymagająca analizy i poważnej refleksji wiąże się z rozwojem intelektualnym człowieka. Badania wskazują wiele związanych z tym zagrożeń, na przykład:

$\rightarrow$ zaburzenia funkcji poznawczych (zakłócenia percepcji, zmniejszona płynność uwagi, ograniczenie lub utrata zdolności logicznego myślenia, natrętne myśli),

$\rightarrow$ bierność intelektualna,

$\rightarrow$ upośledzenie pamięci (wynikające $z$ braku treningu pamięci i z mylnego przekonania, że skoro wszystkie informacje można znaleźć w internecie, to zapamiętywanie jest zbędne),

$\rightarrow$ fałszywy lub fragmentaryczny obraz świata (postrzeganie świata jako ciągu wideoklipów, a nie jako wzajemnie powiązanych i zależnych od siebie zjawisk), niedojrzałość intelektualna (traktowanie świata kreowanego jako rzeczywistego),

$\rightarrow$ niedorozwój umiejętności systematycznego uczenia się,

$\rightarrow$ osłabienie umiejętności wysławiania się i pisania, bezkrytyczne naśladownictwo, przewaga myślenia konkretno-obrazowego nad abstrakcyjnym, obniżona zdolność do syntezy i uogólnienia oraz analizy i dostrzegania relacji, a w konsekwencji - obniżona zdolność wnioskowania i rozumienia,

$\rightarrow$ niezdolność do konstruowania pełnych, logicznych i spójnych wypowiedzi, niezdolność do twórczego użycia języka, dominacja "stylu" internetowego oraz nieznajomość odmian stylistycznych języka mówionego i pisanego.

Wiele zagrożeń osobistych wiąże się również z rozwojem emocjonalnym dzieci i młodzieży:

$\rightarrow$ uczucia przyjaźni, miłości, troski, odpowiedzialności widziane są przez zniekształcający pryzmat na przykład gier komputerowych (to samo dotyczy relacji "dobro - zło" w uproszczonym świecie gracza), niedojrzałość emocjonalna,

$\rightarrow$ budowanie niewłaściwych emocji dotyczących miłości i życia seksualnego, traktowanie relacji zapośredniczonych medialnie jako rzeczywistych, 
$\rightarrow$ tworzenie negatywnych wzorów wyrażania emocji, eskalacja niekontrolowanych emocji w sieci,

$\rightarrow$ procesy torowania na treści, zachowania i postawy wychowawczo niepożądane oraz desensytyzacja kognitywna i emocjonalna,

$\rightarrow$ uzależnienia: zespół uzależnienia od internetu (internet addiction disorder, internet addiction syndrome), syndrom zmienionych stanów świadomości (altered states of consciousness) - przypominający stany upojenia alkoholowego i intoksykacji farmakologicznej, zespół FOMO, czyli lęk przed utratą ważnych informacji lub ważnego wydarzenia, a także syndrom nałogowej gry (zachowań hazardzisty), w tym także uzależnienia od programów zawierających elementy psychomanipulacji, technik perswazyjnych i bodźców podprogowych (wideoklipy, reklamy, muzyka techno), być może także bazujących na procedurach programowania neurolingwistycznego, na technikach kontroli umysłu czy technikach bioneuromanipulacyjnych,

$\rightarrow$ dyskomfort psychiczny związany z "syndromem odstawienia",

$\rightarrow$ zachowania kompulsywne, nerwice.

Zagrożenia osobowe dotyczą również rozwoju moralnego, w tym zwłaszcza: zaburzenia hierarchii wartości i ich relatywizacji oraz nierespektowania zasad etycznych (nie obowiązują one w części gier).

Analizując potencjalne niebezpieczeństwa związane z rozwojem najnowszych technologii informacyjno-komunikacyjnych, nie można pominąć również zagrożeń rozwoju kompetencji społecznych dzieci i młodzieży, takich jak:

$\rightarrow$ alienacja społeczna i osłabienie więzi rodzinnych, ucieczka od realnego świata,

$\rightarrow$ dostęp do materiałów pornograficznych i rasistowskich oraz do patologicznych i „toksycznych" grup kultowych,

$\rightarrow$ traktowanie agresji i przemocy jako pożądanych zachowań społecznych, ksenofobia, powielanie zachowań patologicznych i destrukcyjnych (społeczne konsekwencje torowania poznawczego ku treściom niepożądanym wychowawczo), desensytyzacja społeczna,

$\rightarrow$ brutalność zachowań i wypowiedzi, wynikająca z poczucia „anonimowości" i „bezkarności”, nieuzasadniona indywidualna lub zbiorowa agresja i autoagresja,

$\rightarrow$ relatywizacja relacji społecznych, dezintegracja obrazu świata. 
Wiele powyższych zagrożeń odnotowano już w początkowym okresie budowy i upowszechniania internetu w Polsce (Tanaś 2005, s. 25-40), a postawione wówczas diagnozy okazały się, niestety, trafne.

Bez wątpienia wspomniane niebezpieczeństwa rozwojowe ściśle się wiążą z dużą grupą oddziaływań groźnych społecznie, takich jak:

$\rightarrow$ analfabetyzm cyfrowy i wykluczenie społeczne - kwestie te dotyczą osób ubogich, niezamożnych, bezrobotnych, pozbawionych dostępu do sieci, urządzeń mobilnych czy smartfonów, a także licznych grup osób z niepełnosprawnościami, osób bez kompetencji informatycznych, technologicznych i medialnych. Zagrożenia tego rodzaju mają znaczenie dla mieszkańców tych wsi i małych miasteczek, w których działają szkoły bez szerokopasmowego internetu, właściwej infrastruktury i wi-fi - czyli miejsc, w których nie ma możliwości komunikacji sieciowej, bez dostępu lub z utrudnionym dostępem do otwartych zasobów edukacyjnych, otwartej nauki i innych internetowych źródeł wiedzy i kultury,

$\rightarrow$ zachowania ryzykowne - podejmowanie działań i czynów ryzykownych wraz z ich opisywaniem lub rejestrowaniem dźwiękowym, wizualnym lub audiowizualnym oraz z udostępnianiem dzieciom i młodzieży intencjonalnie tworzonych materiałów. Szczególnie krytyczny jest okres dojrzewania. Podatność na zachowania ryzykowne spowodowana jest przez czynniki psychobiologiczne i ewolucyjne (Romer 2010; Steingerg 2007). Technologie informacyjne $i$ komunikacyjne $z$ jednej strony fascynują nastolatków, zaspokajając niektóre z głównych potrzeb emocjonalnych i komunikacyjnych ważnych w okresie dojrzewania (Dolev-Cohen, Barak 2013; Valkenburg, Peter 2011), z drugiej są sposobem manifestowania wielu ryzykownych zachowań online. Internet ułatwia udział w sytuacjach zwiększających prawdopodobieństwo wystąpienia takich negatywnych konsekwencji jak stres emocjonalny, wiktymizacja lub pogorszenie funkcjonowania społecznego oraz szkolnego czy akademickiego (Valcke, De Wever, Van Keer, Schellens 2011). Najczęściej odnotowywanym problemem związanym z zachowaniami online była dotychczas cyberprzemoc (Livingstone, Smith 2014; Young, de Abreu 2011). W ostatnich latach większą uwagę zwraca tendencja korzystania z sieci w celu kontaktu z nieznajomymi osobami, grupami spo- 
łecznymi czy instytucjami, związkami i organizacjami (Valcke i in. 2011). Wyniki badań (Gámez-Guadix, Borrajo, Almendros 2016) wskazują również na duże znaczenie charakterystycznej dla okresu dojrzewania impulsywności (nieodpowiedzialność jako możliwy mechanizm wyjaśniający podejmowanie zachowań ryzykownych). Coraz powszechniejsza jest utrata kontroli nad korzystaniem z internetu oraz nadmierne poznawcze zaabsorbowanie jego wykorzystaniem i dalszym używaniem, i to mimo negatywnych konsekwencji (Caplan 2010). Problem ten bywa nazywany użyciem kompulsywnym (Meerkerk, van den Eijnden, Franken, Garretsen 2010) lub uzależnieniem od internetu (Smahel, Brown, Blinka 2012),

$\rightarrow$ potencjalny wzrost bezrobocia jako skutek tego, że w najbliższych latach zniknie wiele istniejących zawodów, które wykonują obecnie miliony ludzi na całym świecie. Pojedyncze osoby i całe przedsiębiorstwa opierają na tych zawodach swoją działalność lub związały się z osobami je wykonującymi. Proces likwidacji wielu zawodów jest realny i już trwa („The Guardian” 2017). Wyniki badań prowadzonych przez Uniwersytet Oksfordzki i wiele innych ośrodków akademickich, które przytacza Alux.com (2016/2017), wskazują, że w najbliższych dwudziestu latach nastąpi znaczna redukcja zatrudnienia $\mathrm{w}$ piętnastu powszechnie uprawianych zawodach, takich jak rolnik, kierowca, kasjer w supermarkecie, agent w biurze podróży, pracownik fabryki, dyspozytor, barman, pracownik restauracji (waiting tables), kasjer bankowy, pilot wojskowy i żołnierz, pracownik sieci fast food, telemarketer, księgowy, pracownik giełdy (stock trader), pracownik firm budowlanych. Mimo istniejących problemów podstawą dalszych działań akademickich i oświatowych powinno być podejmowanie decyzji dotyczących zarówno realizowanych współcześnie kierunków kształcenia, jak i dokształcania oraz przekwalifikowywania osób zatrudnionych w wymienionych zawodach. Brak poważnej refleksji w zakresie nauk społecznych i zaniedbanie intencjonalnych, mądrych działań edukacyjnych może skutkować kryzysami politycznymi, ekonomicznymi i społecznymi, przede wszystkim zaś ludzkimi tragediami,

$\rightarrow$ niekontrolowany handel danymi osobistymi i nieetyczne ich wykorzystanie - proces rozwoju technologii informacyjno-komu- 
nikacyjnych wyprzedza ludzką świadomość konsekwencji, jakie ze sobą niesie, a także legislacyjne regulacje. Olbrzymie ilości danych, uzyskiwane dzięki cyfryzacji mediów, rozwojowi oprogramowania oraz usieciowieniu, mają nie tylko dużą objętość (high volume), dużą intensywność strumienia (high velocity), ale także dużą różnorodność (high variety) i zróżnicowaną wiarygodność (high veracity). Zestawy danych, których rozmiar lub typ przekracza możliwości tradycyjnych algorytmów i relacyjnych baz danych do ich przechwytywania, zarządzania i przetwarzania, przyjęto nazywać terminem big data. Ich analiza pozwala podejmować niedostępne dotychczas decyzje, i to na wielu polach. Bez wątpienia otwiera to zupełnie nowe perspektywy poznawcze, ale także rodzi możliwość nieetycznego, a nawet przestępczego wykorzystania tych informacji,

$\rightarrow$ przestępczość kryminalna i cywilna - terroryzm kryminalny, działania mafijne, propagowanie i udostępnianie instrukcji dotyczących na przykład popełnienia samobójstwa, morderstwa, gwałtu, skonstruowania broni lub bomby czy produkcji narkotyków, upowszechnianie zjawisk przestępczych lub społecznie niepożądanych (sekciarstwo religijne, wrogość wobec grup etnicznych, narodów czy grup społecznych o odmiennej identyfikacji klubowej w sporcie), zagrożenie bezpieczeństwa instytucji, przemoc z użyciem narzędzi cyfrowych, mobbing, kradzież tożsamości i podszywanie się w celu odniesienia korzyści materialnych, dezinformacja i manipulacja medialna, rozpowszechnianie patotreści, inicjowanie i tworzenie grup antysocjalnych,

$\rightarrow$ terroryzm - atak na instytucje, bezpośrednia ingerencja w wewnętrzne sprawy kraju, terroryzm polityczny, zagrożenie bezpieczeństwa informacyjnego państwa, możliwość odbywania treningów w wirtualnych światach i ataki służące opanowaniu umiejętności dokonywania rekonesansu, inwigilacji, współpracy w grupach, analizy możliwej reakcji medialnej.

Kolejną grupę stanowią dostrzegane i sygnalizowane społecznie zagrożenia kulturowe:

$\rightarrow$ upowszechnienie makaronizmów (wolapik) i błędnych konstrukcji językowych, 
$\rightarrow$ zanik terytorialnego zróżnicowania języka (homogenizacja języka),

$\rightarrow$ przenoszenie wzorców zachowań, rytuałów i obrzędów wyrwanych z kontekstu kulturowego do innego obszaru kulturowego, uniformizacja kultury i ubioru,

$\rightarrow$ wchłanianie mniejszości kulturowych i językowych przez większe kultury,

$\rightarrow$ nasilenie konfliktów kulturowych,

$\rightarrow$ zagrożenie tożsamości kulturowej (stres społeczny niektórych grup),

$\rightarrow$ manipulacja kulturowa - oddziaływanie na poglądy i postawy przez kulturę.

Warto w tym miejscu przypomnieć najważniejsze prawo kodeksu etycznego lekarzy: Primum non nocere (po pierwsze, nie szkodzić). Po wiekach stało się ono również naczelną zasadą etyczną badań naukowych i działań społecznych. Zasada ta ma ponadto olbrzymie znaczenie dla tych pedagogów i nauczycieli, którzy wkraczają w przestrzeń komputerów, telefonii komórkowej oraz internetu, usiłując zrozumieć losy dzieci i młodzieży w elektronicznej jaskini świata mediów cyfrowych.

Dla bezpieczeństwa dziecka groźna jest przede wszystkim informacyjno-propagandowa funkcja sieci, która wprawdzie daje spore możliwości poznawcze, ale jednocześnie uniemożliwia przeprowadzenie odbiorcy właściwej samooceny i utrudnia mu znalezienie odpowiedniego miejsca w rzeczywistości, a przez szybkość przekazu i wielość równolegle działających kanałów pozbawia go czasu potrzebnego na refleksję i działanie. Znaczenie ma również pomieszanie rzeczywistości realnej i medialnej, powodujące powstawanie niespójnej, nieciągłej wizji świata, przynosząc w rezultacie chaos etyczny, światopoglądowy i zaburzenia osobowości. Trzecią istotną kwestią jest pogoń za zabawą za wszelką cenę, koncentrowanie się na chwilowym zysku i przyjmowanie konsumpcyjnego stylu życia, co grozi zagubieniem informacyjnym, zaburzeniem poczucia tożsamości i rozumienia rzeczywistości. I wreszcie - treści zamieszczone w internecie rodzą sprzeczność celów i treści wychowawczych, powodują ponadto wiele negatywnych konsekwencji, takich jak zastępowanie naturalnych relacji międzyludzkich kontaktem z bohaterami gier komputerowych, seriali telewizyjnych, idolami medialnymi. 
Przede wszystkim należy pamiętać, że Konwencja o prawach dziecka została w Polsce ratyfikowana w 1991 r. z zastrzeżeniami i deklaracjami interpretacyjnymi (Zgromadzenie Ogólne Narodów Zjednoczonych przyjęło konwencję w listopadzie 1989 r.). Nie wolno abstrahować od ustaleń tego dokumentu, ale trzeba mieć świadomość koniecznych i nieustannych uzupełnień prawnych, wynikających z rozwoju technologii informacyjno-komunikacyjnych, ale także z przestępczości cywilnej i kryminalnej. Chodzi tu nie tylko o nowe typy zachowań ryzykownych czy czynów przestępczych. Nawet tradycyjna przestępczość zyskuje w cyberprzestrzeni nowe terytoria i nieporównywalną siłę rażenia. Przeobrażają się jej formy, następują także zmiany językowe w zakresie konotacji i desygnatów podstawowych pojęć (na przykład inny sens zyskuje tradycyjne alibi „mnie tam nie było”).

Nadmierny konsumpcjonizm i powszechnie dostrzegana dezintegracja społeczna obniżają jakość życia i degradują materialne podstawy rozwoju kraju. Najtrudniejsze i najważniejsze zadania pedagogiczne dotyczą systemu wartości cyfrowego pokolenia, jego aspiracji, postaw, zachowań oraz stylów życia. Wiele lat temu Bogdan Suchodolski (1937) trafnie przewidywał, że przyszłość rozegra się w sferze szeroko rozumianej kultury. Trzeba się zgodzić z konstatacją, że ożywieniu tradycji kultury europejskiej, ideom tolerancji i humanizmu musi towarzyszyć dbałość o harmonijny rozwój dzieci i młodzieży. Symboliczne wartości wolności, równości i braterstwa będą martwe bez nowej orientacji pedagogicznej i edukacji skierowanej z jednej strony na suwerenność jednostki, z drugiej zaś na rekonstrukcję ludzkiej wspólnoty.

Wirtualna rzeczywistość usiłuje naśladować realny świat, ale jest od niego odmienna. Odmienne od wcześniejszych systemów jest także kształcenie korzystające z mediów cyfrowych. Dlatego wyzwaniem dla polskiej oświaty i polityki na początku XXI w. jest edukacja informacyjna i medialna. Pedagodzy, nauczyciele i rodzice, politycy, prawnicy, psychologowie i lekarze, uczeni i praktycy powinni zatem wspólnie zadbać o to, by ta edukacja nie była wybrakowana i bezrozumna. Problemem współczesnych systemów kształcenia i edukacji jest nie tylko sfera intelektualna człowieka i sprawność jego działania, lecz również sfera wartości. Realizując odwieczne marzenia o przekraczaniu własnych granic biologicznych, temporalnych i terytorialnych, wybudowaliśmy sobie elektroniczną jaskinię. Trzeba się teraz nauczyć, jak w niej żyć 
możliwie najpełniej i jak dostarczać intelektualny pokarm oraz ruch i świeże powietrze naszym dzieciom.

Znamienne, że przytoczone wcześniej klasyfikacje, choć stosunkowo nowe, już teraz domagają się uzupełnień. Społecznością sieciową co jakiś czas wstrząsają informacje o kolejnych niepokojących zjawiskach, takich jak patostreaming, nowe formy ataków ransomware, ryzykowne wyzwania internautów czy wreszcie zespół objawów przeciążenia informacyjno-komunikacyjnego, który można określić mianem cyberwypalenia (Galanciak, Siwicki 2018).

Katalog problemów, z których wiele dotyczy aktywności podejmowanych przez młodych internautów, poszerza się w zatrważającym tempie. Jest to ogromne wyzwanie nie tylko dla rodziny jako podstawowego środowiska wychowawczego, ale także dla szkoły, stanowiącej dla młodego człowieka kluczową przestrzeń socjalizacji i edukacji, oraz dla nauk społecznych na czele z pedagogiką, wyposażoną w bogaty arsenał metod, środków i narzędzi badawczych uwzględniających specyfikę dziecka jako podmiotu aktywnego w środowisku społecznym. Nauka jednak nie nadąża za tempem przemian zachodzących w przestrzeni medialnej. Jej żarna, domagające się od badacza precyzji i głębokiego namysłu nad przedmiotem badań, mielą dokładnie, lecz wolno, co często sprawia, że naukowcy czują się bezradni wobec rzeczywistości medialnej, a młodzi użytkownicy sieci są bezbronni wobec pojawiających się zagrożeń. Tymczasem człowiek, coraz silniej integrujący pierwiastek realny i wirtualny, potrzebuje wsparcia w procesie kształtowania cyfrowych kompetencji, zarówno w celu unikania zagrożeń, jak i po to, aby móc optymalnie wykorzystać szanse i możliwości - poznawcze, twórcze i społeczne - jakie roztacza przed nim cyberprzestrzeń. Odpowiedzialność spoczywająca na naukach społecznych, w tym na pedagogice, jest zatem ogromna i wymaga determinacji w podejmowaniu ciągłych prób oglądu nowej rzeczywistości, bez względu na to, jak krótkotrwały może być skutek takiej analizy i jak szybko będzie się ona domagać rewizji. Trzy podstawowe obszary zagrożeń związanych z aktywnością w sieci - kontakty z nieodpowiednimi treściami, podejmowanie niebezpiecznych działań społecznych, przestępczość elektroniczna wymierzona przeciwko systemom bezpieczeństwa - wymagają ciągłego monitoringu, diagnozowania i dostarczania rozwiązań, umożliwiających przeciwdziałanie negatywnym zjawiskom, a także 
wypracowywania strategii terapeutycznych dla ofiar sytuacji, którym nie udało się zapobiec.

Żeby w pełni zrozumieć problemy związane z bezpieczeństwem dzieci i młodzieży w sieci, konieczne jest uwzględnienie perspektywy technicznej oraz dostrzeżenie ogromnego znaczenia działań ochronnych i wyprzedzających. Zapewnienie bezpieczeństwa od strony technicznej wymaga co najmniej:

$\rightarrow$ ochrony domenowej i blokowania stron naruszających prawo na podstawie ich czarnej listy,

$\rightarrow$ skanowania i sprawdzania zawartości strony internetowej w celu ewentualnego blokowania jej szkodliwej zawartości,

$\rightarrow$ analizy online przesyłanych i udostępnianych treści pod kątem bezpieczeństwa użytkowników.

Stała walka z istniejącymi oraz coraz nowszymi rodzajami wirusów i typów ataków trwa. Rozwój technologiczny rodzi kolejne zagrożenia. Media cyfrowe mogą być wykorzystywane dla dobra użytkownika, ale także przeciwko niemu. Rośnie na przykład liczba urządzeń komunikujących się między sobą, a obejmowanych wspólnym mianem „internetu rzeczy" (internet of things). Według raportu Computer Emergency Response Team Polska (2016, s. 23-29) już w 2016 r. złośliwe oprogramowanie pozwoliło hakerom przejąć za pomocą botnetu Mirai ogromną liczbę kamerek internetowych oraz Smart TV i sparaliżować serwisy Twitter, Spotify, Reddit, „New York Times” czy "Wired”. Zainfekowano wówczas około dwóch i pół miliona inteligentnych lodówek, maszyn przemysłowych oraz urządzeń parkingowych. To tylko jeden z przykładów walki o bezpieczeństwo użytkowników na polu technicznym. Zagrożeniom i incydentom globalnym towarzyszą uderzenia w poszczególne kraje, instytucje lub osoby prywatne, a także złośliwe ataki losowe.

Analiza zagrożeń technicznych to na tyle szerokie zagadnienie, że nie można go zamknąć w niniejszym artykule. Wypada jednak wskazać, że obecnie rozwijają się nie tylko wspomniany "internet rzeczy", ale także dziedzina rozpoznawania mowy i języków, rozszerzona rzeczywistość, wreszcie - sztuczna inteligencja i robotyka. Rośnie zarówno liczba zagrożeń, jak i wachlarz metod i środków ich wykrywania oraz zwalczania. Toczy się - często brutalna i bezwzględna - wojna o bezpieczeństwo sieci i jej użytkowników. Aby zrozumieć to zjawisko, 
konieczne jest uwzględnienie obu perspektyw: technicznej i humanistyczno-społecznej.

\section{Złożoność problemu - przykład cyberprzemocy}

Jednym z kluczowych problemów związanych z ryzykownymi zachowaniami podejmowanymi przez internautów jest cyberprzemoc. $Z$ definicji przyjętej przez Organizację Narodów Zjednoczonych wynika, że jest to "każde intencjonalne, agresywne działanie podejmowane przez grupę lub osobę używającą elektronicznej formy kontaktu przeciwko ofierze, która nie może się łatwo obronić" (2014, s. VII [przekład własny]). Ta z pozoru zwięzła definicja kryje w sobie szeroki zakres różnych przejawów agresji elektronicznej. Za cechy wspólne dla tego rodzaju form przemocy uznaje się: „użycie środków elektronicznych, intencjonalność działania, nierównowagę sił (może polegać na przewadze liczebnej prześladowców, do których dołączają obserwatorzy, ale także na sprawności w korzystaniu przez nich z technologii np. podczas włamania na konto lub podmiany plików), powtarzalność zachowań (długotrwałość dręczenia - w sieci przybiera na sile, bo to, co raz wrzucone do internetu, nie znika, lecz ulega powieleniu i często modyfikacjom wzmacniającym siłę rażenia), poczucie anonimowości - fizycznej separacji od ofiary, ułatwiające dręczenie ze względu na ograniczenie dyskomfortu psychicznego wynikającego z oglądania przez dręczycieli skutków przemocy" (Pyżalski 2012a; Tłuściak-Deliowska 2017).

Wartościową propozycję systematyzacji zjawisk związanych z cyberprzemocą przygotował Jacek Pyżalski (2012a, s. 126-128), a jej aktualizacji dokonał Maciej Tanaś w sporządzonej dla Najwyższej Izby Kontroli opinii na temat europejskich rozwiązań prawnych i organizacyjnych w zakresie zapobiegania cyberprzemocy (Tanaś 2018, s. 72). W myśl ustaleń badaczy pojęcie agresji elektronicznej obejmuje następujące formy:

$\rightarrow$ flaming - agresywna wymiana zdań, na przykład na czacie lub w ramach grupy dyskusyjnej,

$\rightarrow$ prześladowanie (harassment) - regularne przesyłanie nieprzyjemnych wiadomości do ofiary za pomocą elektronicznych kanałów komunikacji, zwane także prześladowaniem w sieci (online harassment),

$\rightarrow$ griefing - prześladowanie kogoś w grze internetowej albo w świecie wirtualnym, 
$\rightarrow$ trolling - uparte umieszczanie w sieci złośliwych komentarzy na czyjś temat,

$\rightarrow$ cyberprześladowanie (cyber-persecution, cyberbullying) - ciągłe, powtarzalne prześladowanie, stosowanie gróźb, atakowanie ofiary w internecie,

$\rightarrow$ maskarada (masquerade) - tworzenie przez osobę dokonującą prześladowania fałszywych profili internetowych w celu zaszkodzenia komuś,

$\rightarrow$ fraping - zmiana detali czyjegoś konta na Facebooku w celu upokorzenia tej osoby,

$\rightarrow$ dissing-umieszczanie w internecie okrutnych informacji, zdjęć, filmów dotyczących dzieci,

$\rightarrow$ grooming - zaprzyjaźnianie się z dzieckiem, czasem z jego rodziną, aby obniżyć poziom zahamowania dziecka na napastowanie seksualne,

$\rightarrow$ sexting cyberbullyingowy - wymienianie się zdjęciami o wymowie seksualnej bez wiedzy i zgody ofiary,

$\rightarrow$ sexcasting - wymienianie się filmami o wymowie seksualnej bez wiedzy i zgody ofiary,

$\rightarrow$ happy slapping - nagrywanie agresywnych wypowiedzi lub zachowań wobec kogoś, a następnie rozsyłanie nagrań do znajomych lub umieszczanie ich w internecie,

$\rightarrow$ kradzież tożsamości (impersonation) - podszywanie się pod ofiarę, a także kradzież tożsamości ofiary online (catfishing) w celu odtworzenia jej społecznej sieci powiązań w internecie i zdobycia informacji o ofierze lub o jej znajomych albo dokonania maskarady,

$\rightarrow$ upublicznianie tajemnic (outing) - udostępnianie prywatnych materiałów ofiary (na przykład zdjęć, zapisów rozmów),

$\rightarrow$ naciąganie (trickery) - udostępnianie osobom trzecim prywatnych materiałów, w których posiadanie wszedł sprawca (na przykład zdjęć, zapisów rozmów) bez zgody ofiary (podstępem lub przez wymuszenie),

$\rightarrow$ śledzenie (cyberstalking) - inwigilacja ofiary i nękanie jej niechcianymi komunikatami,

$\rightarrow$ poniżenie (denigration), zwane także oczernianiem - upublicznienie poniżających, nieprawdziwych informacji lub materiałów na temat ofiary, 
$\rightarrow$ wykluczenie (exclusion) - celowe usunięcie z listy kontaktów internetowych lub niedopuszczenie do niej ofiary,

$\rightarrow$ zniesławianie (defamation) - komunikacja werbalna oparta na złośliwym plotkowaniu bez posiadania materiałów dotyczących zniesławianego (podobnie jak poniżanie),

$\rightarrow$ księgi obelg (slam books) - wersje elektroniczne papierowych notatników krążących wśród dzieci i nastolatków, z pytaniami, na które należy udzielić odpowiedzi. Zawierają one złośliwe, zazwyczaj anonimowe komentarze mające na celu prześladowanie lub zniesławianie,

$\rightarrow$ agresja techniczna - działania przeciwko sprzętowi komputerowemu ofiary, nie bezpośrednio przeciwko samej ofierze (Pyżalski 2012a, s. 126-128; por. Tanaś 2018, s. 72-73).

Długa lista występujących form cyberprzemocy uświadamia z jednej strony, z jak skomplikowanym i wielowymiarowym zjawiskiem mamy do czynienia, z drugiej zaś strony udowadnia, że niezbędna jest intensywna praca nad opartą na edukacji profilaktyką dotyczącą tego typu zachowań, zwłaszcza wśród dzieci i młodzieży, czyli grup szczególnie narażonych na cyberprzemoc rówieśniczą (i nie tylko), a także podatnych na jej osobiste i społeczne skutki. Badania prowadzone w ostatnich latach pokazują, że skala problemu jest bardzo duża. Z raportu Nastolatki 3.0, przygotowanego przez zespół badawczy Naukowej i Akademickiej Sieci Komputerowej, wynika, że ponad połowa polskich nastolatków była świadkiem agresji wobec swoich znajomych w przestrzeni wirtualnej, $59,7 \%$ doświadczyło wyzywania kolegi czy koleżanki, niewiele mniej - 58,1\% - poniżania lub ośmieszania, 40,5\% spotkało się z sytuacją podszywania się pod znajomych, a 34,2\% - straszenia (Kamieniecki i in. 2017, s. 86-87). Ponad 30\% respondentów doświadczyło internetowej agresji słownej: 32,2\% było wyzywanych, 19,4\% poniżanych, a 13,6\% - straszonych (tamże, s. 89). Podobne wyniki pojawiają się w raporcie Najwyższej Izby Kontroli dotyczącym zapobiegania i przeciwdziałania cyberprzemocy wśród dzieci i młodzieży, w którym 26,7\% ankietowanych uczniów przyznało, że padło ofiarami cyberprzemocy (Zapobieganie i przeciwdziałanie... 2018, s. 25-27). Co niepokojące, w obu przywoływanych badaniach bardzo wysoki odsetek stanowią osoby, które deklarują, że u nikogo nie szukały (lub nie będą szukały) pomocy, jeśli agresja internetowa bezpośrednio ich dotknie - odpo- 
wiednio 39\% w badaniu Naukowej i Akademickiej Sieci Komputerowej (Kamieniecki i in. 2017, s. 91) i 48,8\% w badaniu Najwyższej Izby Kontroli (Zapobieganie i przeciwdziałanie..., 2018, s. 54-55). Brak wsparcia ze strony środowiska może skutkować u osoby prześladowanej poważnymi konsekwencjami natury psychospołecznej (takimi jak izolacja rówieśnicza, poczucie osamotnienia, depresja, obniżenie samooceny, a w skrajnych sytuacjach - podjęcie próby samobójczej). Tymczasem, jak wykazuje przywoływany raport Najwyższej Izby Kontroli, działania przeciwdziałające cyberprzemocy nie są w Polsce koordynowane, co nie sprzyja właściwemu ich ukierunkowaniu i zwymiarowaniu, a tym samym obniża ich skuteczność. Szkoły nie otrzymują dostatecznego wsparcia merytorycznego i technicznego w tym zakresie od władz państwowych, organów prowadzących ani kuratoriów, przez co koncentrują swoje działania na reagowaniu na zgłaszane akty cyberprzemocy (Zapobieganie i przeciwdziałanie... 2018, s. 13). Sytuacja taka z pewnością nie sprzyja rozwiązaniu problemu i zwiększeniu bezpieczeństwa dzieci w internecie.

\section{Nowe aktywności, nowe problemy}

Mimo niedostatków w polityce diagnozowania cyberprzemocy i jej profilaktyce jest ona jednym z najlepiej zbadanych zagrożeń związanych z obecnością w sieci. Większość zjawisk niebezpiecznych z obszaru cyfrowego świata pozostaje jednak mało rozpoznana. Wśród nich są takie zjawiska z grupy zachowań ryzykownych jak sexting (obecny w dyskursie społecznym między innymi dzięki kampanii "Myślę, więc nie ślę" Fundacji Dajemy Dzieciom Siłę), niebezpieczne wyzwania internetowe (challenge) lub patostreaming, zyskujący wśród odbiorców coraz większą popularność.

Sexting, polegający na „wysyłaniu roznegliżowanych zdjęć lub krótkich filmików o treści erotycznej do drugiej osoby [...] za pomocą telefonu komórkowego (usługa MMS) i internetu (email)" (Ronatowicz 2014, s. 129), to nie tylko odzwierciedlenie potrzeb emocjonalnych uprawiających go osób, a w wydaniu komercyjnym - także ekonomicznych (na przykład wysyłka zdjęć o charakterze erotycznym w zamian za doładowanie telefonu), ale przede wszystkim świadectwo braków w rozwoju etycznym i emocjonalnym. Justyna Woźniak (2018, s. 204-205) przedstawiła następujący model procesu angażowania się w sexting:

$\rightarrow$ faza zainteresowania, przejawiająca się między innymi w fascynacji zjawiskiem przeglądania autopornografii innych osób, 
$\rightarrow$ faza wstępna, w której pojawia się chęć uczestnictwa w sextingu,

$\rightarrow$ faza aktywności, która może rozwinąć się dwojako: zyskać aprobatę społeczną (nagroda i zachęta do kontynuowania działań) lub wywołać dezaprobatę, szyderstwa, a w skrajnym wypadku - nienawiść,

$\rightarrow$ faza komercyjna, która nie odnosi się do wszystkich osób uprawiających sexting, polega zaś na czerpaniu korzyści finansowych z rozsyłania autopornografii lub prezentowania własnego roznegliżowanego ciała w sieci przy użyciu kamerki internetowej.

Młodzi ludzie uwikłani w sexting, przy braku dostatecznej edukacji zarówno seksualnej, jak i medialnej, często nie zdają sobie sprawy ze skali grożących im konsekwencji - nie tylko moralnych, ale także społecznych, które zwykle są przez nich postrzegane jako bardziej dotkliwe. Materiały, które raz trafią do sieci, nigdy nie znikają z niej całkowicie, zwłaszcza w czasach szybkiego dzielenia się treściami za pośrednictwem portali społecznościowych. Osoby, które na skutek wycieku intymnych materiałów do internetu padły ofiarą agresji, ośmieszenia, szantażu czy kompromitacji, będą zmuszone zmagać się z konsekwencjami tych działań w kolejnych latach. Ostracyzm środowiska, długotrwałe poczucie wstydu, załamanie szansy na karierę zawodową czy trudności z ułożeniem sobie życia prywatnego to tylko nieliczne z możliwych skutków tego niebezpiecznego zjawiska.

Innym zagrożeniem wynikającym z potrzeby autoprezentacji i uzyskania akceptacji środowiska, jak również potrzeby rywalizacji i współuczestnictwa w działaniach podejmowanych przez grupę, jest zjawisko podejmowania niebezpiecznych wyzwań internetowych. Należy przy tym podkreślić, że wiele z nich ma wydźwięk pozytywny, służy propagowaniu prospołecznych postaw lub wsparciu celów charytatywnych (na przykład słynne ice bucket challenge, szerzące wiedzę na temat stwardnienia zanikowego bocznego i umożliwiające zbieranie pieniędzy na organizację wspierającą osoby dotknięte tą chorobą). Istnieją jednak i takie wyzwania, które mogą stanowić realne zagrożenie dla zdrowia i życia podejmujących je osób. Do tej grupy należą między innymi choking game (zabawa w podduszenie i osiąganie w ten sposób stanu euforii), game of 72 (ucieczka z domu na trzy doby, szczególnie popularna wśród młodszych nastolatków) czy ice and salt challenge (posypanie dłoni solą, a następnie umieszczenie na niej lodu - efektem 
bywają poparzenia, nawet drugiego stopnia). Co jakiś czas przez media przetaczają się także fale sensacyjnych doniesień na temat wyzwań samobójczych, takich jak Niebieski wieloryb czy Lalka Momo, o których informacje, jakkolwiek stanowią zwykle klasyczne przykłady tak zwanego zaniepokojenia społecznego (moral panic), to same z siebie mogą być zachętą dla młodych internautów poszukujących tożsamości lub nieradzących sobie z emocjami.

Coraz groźniejszym zjawiskiem staje się także patostreaming, polegający na prezentowaniu na żywo w sieci aspołecznych, bulwersujących zachowań, takich jak wyzywanie przypadkowych ludzi, przemoc wobec innych (jeden ze streamerów zasłynął pobiciem matki za pomocą krzesła), libacje alkoholowe czy namawianie nieletnich do rozbierania się przed kamerkami internetowymi. Komentarze zamieszczane na serwisach streamingowych (głównie YouTube) wskazują niepokojący fakt, że dużą grupę widzów i aktywnych komentatorów patostreamów stanowią dzieci. Twórcy tego rodzaju materiałów kierują się chęcią zarobku (fani dokonują wpłat na rzecz swoich ulubieńców), szokowania, przekraczania granic społecznej akceptacji. Dzieci, które nie są w stanie dostrzec następstw różnego rodzaju działań, nie mogą również dokonać właściwej oceny sytuacji, obserwując więc relacje, czerpią z najgorszych wzorców zachowań społecznych, a w konsekwencji uczą się aspołecznych postaw i mogą postrzegać je jako atrakcyjne. Nawet jeśli poczynania patostreamerów są wyśmiewane, to ich programy powodują, że publiczność oswaja się z niewłaściwymi zachowaniami w życiu społecznym, co prowadzi do przyzwolenia na drobną przestępczość, postrzegania agresji jako zabawy, a głupoty jako atrakcyjnej cechy przynoszącej finansowe profity. Odmalowywany w ten sposób nowy wzór kultury stanowi istotne zagrożenie dla respektowanego społecznie zbioru postaw i wartości, dla obowiązującego ładu aksjonormatywnego.

\section{Sposoby przeciwdziałania}

Przeciwdziałanie zagrożeniom występującym w cyberprzestrzeni może zmierzać w dwóch głównych kierunkach. Pierwszy z nich, niezwykle trudny do realizacji ze względu na transgraniczny charakter internetu, dotyczy kodyfikacji prawnej zachowań niebezpiecznych i zastosowania kar. Brak możliwości regulowania zachowań skutkujących na terytorium danego państwa, ale inicjowanych poza jego granicami, uniemożliwia skuteczną penalizację patologicznych zachowań w sieci (Kulesza 2012, s. 11) 
i niezwykle utrudnia ściganie sprawców ewidentnych, skodyfikowanych przestępstw (pedofilia, kradzieże w bankowości elektronicznej). Ponadto, ze względu na idee wolnościowe towarzyszące internetowi od początku jego istnienia, wszelkie działania związane $z$ ingerencją w treści zamieszczane w sieci wywołują reakcję - protesty społeczne przeciwko kontroli internetu (por. losy dokumentów ACTA, PIPA lub SOPA). „Okazuje się, że młodzi internauci, reprezentujący już nowy typ wrażliwości społecznej, posługujący się nowymi nośnikami informacji, nową symboliką, wyrażający swoje zaangażowanie w niekonwencjonalny często sposób, stając przed wyzwaniami, którym nie są w stanie sprostać, potrafią szybko uruchomić potężne zasoby społeczne w przestrzeni internetu dla obrony swoich swobód, wolności i demokracji" (Galas 2018, s. 80-81). Jest to siła, której nie należy ani nie wolno marnotrawić. O wiele skuteczniejszym i trwalszym niż sankcje prawne narzędziem zmiany społecznej jest edukacja, i to na nią należy skierować energię oraz zasoby intelektualne młodych ludzi.

Mądra i dojrzała edukacja w zakresie mediów, przygotowująca do ich odbioru i współtworzenia, to jedyna możliwa ścieżka przeciwdziałania zagrożeniom cyfrowego świata, a równocześnie wyzwalania jego twórczego, samorozwojowego i społecznego potencjału. Aby jednak była ona skuteczna, trzeba wyposażyć nauczyciela w narzędzia podejmowania działań diagnostycznych, profilaktycznych, a nawet częściowo terapeutycznych (na przykład trening zastępowania agresji). Ważne jest więc położenie nacisku na należyte wybrzmienie wątków związanych z kompetencjami medialnymi w programach kształcenia nauczycieli.

Konieczne jest także przedstawienie dzieciom alternatywy wobec cyfrowej rzeczywistości - pozasieciowych sfer aktywności, takich jak sport, harcerstwo, uczestnictwo w kulturze czy w życiu społecznym okolicy.

Tego rodzaju działania nie przyniosą jednak rezultatów bez zaangażowania rodziców. Traktowanie smartfonów, tabletów czy komputerów jako technologicznych następców niani, która zajmuje dziecku czas, nie umożliwia nauki mądrego, twórczego korzystania z mediów. Współobecność rodzica, jego towarzystwo podczas wypraw w głąb sieci wydaje się warunkiem sine qua non powodzenia medialnej edukacji dziecka, jego właściwego przygotowania do zanurzenia w cyberprzestrzeni. 


\section{Zakończenie}

Przestrzeń internetu, coraz silniej zintegrowana z przestrzenią rzeczywistą, stała się drugim domem współczesnego człowieka. Jest organizatorem jego czasu wolnego i pożeraczem czasu przeznaczonego na pracę, miejscem i narzędziem komunikacji społecznej, budowania relacji, układania życia prywatnego. Jest obszarem występowania globalizacji, ale także atomizacji społecznej, czy wreszcie terenem manipulacji politycznej, społecznej, kulturowej, polem wojen militarnych i gospodarczych. Jest ponadto przestrzenią poszukiwania, wykonywania i ewaluacji pracy, a dla naukowców - terytorium badań naukowych i źródłem metod, środków i narzędzi badawczych. W tym nagromadzeniu funkcji i zadań jest również miejsce dla ważnych idei pedagogicznych, od początku przyświecających powstaniu internetu, lecz w pełni możliwych do zrealizowania dopiero dziś. Sieć jest przecież emanacją utopijnych idei filozoficznych wskazujących na konieczność syntezy ludzkiej wiedzy i udostępnienia jej całej ludzkości. Koncepcje umysłu kolektywnego w formie noosfery Teilharda de Chardina czy inteligencji zbiorowej Pierre'a Levy'ego inspirowały już akademików pracujących nad siecią łączącą instytucje naukowe, firmy i domy zwykłych ludzi (Galanciak 2016, s. 248). Dziś stają się impulsem do rozwijania szczytnej idei otwartej nauki i edukacji. Otwarte zasoby edukacyjne (open educational resources, OER), czyli materiały edukacyjne udostępniane bezpłatnie za pomocą technologii informacyjno-komunikacyjnych, w skali dotąd niespotykanej demokratyzują dostęp do źródeł ludzkiej wiedzy. Sekundują im MOOCs (massive online open courses) - kursy organizowane dla masowego odbiorcy przez najlepsze uczelnie świata (Massachusetts Institute of Technology, Stanford University, Princeton, Harvard), a także, coraz częściej, instytucje pozaakademickie, na przykład muzea i fundacje.

Od czasu powstania druku świat nie zyskał podobnego narzędzia o tak wielkim potencjale wyrównywania szans edukacyjnych, a przez to i życiowych, niwelowania nierówności społecznych. Aby skorzystać z jego ogromnego potencjału, omijając równocześnie rafy zagrożeń, trzeba dysponować odpowiednimi kompetencjami, których zdobycie bez uprzedniej edukacji w zakresie mediów nie jest i nie będzie możliwe. 